\title{
Translation Microstrategies Used by Visually Impaired Translators
}

\author{
Raden Arief Nugroho ${ }^{1}$, Mangatur Rudolf Nababan ${ }^{1} \&$ Edi Subroto ${ }^{1}$ \\ ${ }^{1}$ Postgraduate Program in Linguistics, Sebelas Maret University, Surakarta, Indonesia \\ Correspondence: Raden Arief Nugroho, Postgraduate Program in Linguistics, Sebelas Maret University, \\ Surakarta, Indonesia. Tel: 62-818-0587-9141. E-mail: raden.arief.nugroho@gmail.com
}

Received: July 21, 2016 Accepted: August 11, 2016 Online Published: September 23, 2016

doi:10.5539/ijel.v6n5p103

URL: http://dx.doi.org/10.5539/ijel.v6n5p103

\begin{abstract}
This paper discusses the microstrategies of translation (Schjoldager et al., 2008) used by visually impaired translators in translating English texts into Indonesian. There are three reasons for using these microstrategies: 1) they are more specific and thorough; 2) they outnumber other translation strategies; and 3) they can show the degree of creativity applied in a translation work (Yang, 2010). In order to collect the data, a translation task was assigned to two subjects of research in this study. The assignment was to translate a psychological text categorized as "very difficult to read" according to Flesch Reading Ease criteria. Six microstrategies were employed by the translators. The microstrategies and their total frequencies are as follows: direct transfer (9), direct translation (17), explicitation (6), paraphrase (3), addition (4), and deletion (4). Surprisingly, a visually impaired translator who has achieved better English proficiency and experienced translation training is less creative than the one who has not, i.e., the translator's creativity does not imply the quality of translation.
\end{abstract}

Keywords: microstrategies, translation, visually impaired translators

\section{Introduction}

"Translation strategy" is a quite popular terminology that is sometimes "exploited" in many translation researches. In addition, this issue arose because translation strategies aim to help translators to overcome translational problems. Translators should get practical benefits from using translation strategies. In similar sense, Molina \& Albir (2002, p. 508) define strategies as "the procedures...used by the translator to solve problems that emerge when carrying out the translation process..."

In Indonesia, Suryandaru (2012) exposes the existence of visually impaired translators who mostly work as semi-professional translators. Basically, these translators use computers equipped with screen reader software to allow them to read text on the computer screen called JAWS (Job Access with Speech). This assertion implies that they use different procedures during translation process.

Since translators become one of the central aspects in translation, the ability to use appropriate translation strategies to overcome translation problems is used as a basis for determining the degree of professionalism in translation practices. The degree of professionalism here refers to the creative solution performed by translators when they face translation problems. Many predominant findings suggest that creativity in translation appears when translators avoid using vocabulary or word-centered translation (Newmark, 1988; Königs \& Kaufmann, 1996; Lörscher, 2002; and Tirkkonen-Condit, 2005). Thus, it is interesting to see whether visually impaired translators who engage in different translation procedures as opposed to sighted translators will generate certain pattern of translation strategies that indicate creativity in translation practice.

Based on the arguments above, the questions addressed in this study are as follows: 1) what are the translation microstrategies used by visually impaired translators? And 2) how creative are visually impaired translators in dealing with translation problems?

\section{Literature Review}

\subsection{Visually Impaired Translators}

Globalization has made a direct impact on the development of translation studies. As the world experiences faster communication and accelerated mobility, translation studies takes part as a bridge to avoid a communication gap. In line with this statement, Cronin (2003, p. 41) is explicit on the connection between translation and globalization when stating that “...translation is all about making connections, linking one culture 
and language to another, setting up the conditions for an open-ended exchange of goods, technologies and ideas."

The statement implies that there is a multidimensional complexity in the nature of translation, as seen from the way translation relates itself to culture, linguistics, and other aspects of expertise. Apart from its intricacies, translation, as a profession, gains more popularity in terms of market demands. Pym (1998), Theologitis (1998), and Archer (2002) provide evidence for a growing demand of professional translation market throughout the world. Therefore, in light of this rapid progress, the translator has been attracting growing attention in the job market.

Disabled people, particularly those who are visually impaired, should also benefit from this positive progress. From this point of departure, it can be seen that the translator's flexibilities, such as unrestricted or static workplace, flexible schedule, opportunity to work on a freelance basis and get a high wage, will be beneficial characteristics (Note 1) to visually impaired people.

However, some may doubt visually impaired people's capability to translate a text. In this regard, translation scholars have created the term Specialized Translation (Note 2) (ST) to accommodate the issue of translation and disabilities. However, with the possibility to explore the phenomenon of visually impaired translators, researchers found little evidence in this area. Studies conducted by Hernández-Bartolomé, Isabel, \& Cabrera (2004), Mcgonigle (2007), and Romero-Fresco (2011) involve the elements of translation and visual impairment. However, these studies do not use visually impaired translators as the focus of study. Their studies show that audiovisual translators produce special translation, film signs, or subtitling for deaf or hard of hearing viewers. This clearly shows that studies on visually impaired translators are still a neglected area of research in specialized translation.

\subsection{Translation Microstrategies}

Macrostrategies affect the text as a whole. These strategies emphasize a larger unit of discourse as their target. Furthermore, the strategies involve both target language (TL) and source language (SL) culture as the most important factor in the translation work. According to Jensen $(2009$, p. 29), macrostrategies practically put translation on a continuum with a spectrum of SL-orientation and TL-orientation.

Given a similar characteristic, those who work in translation research will probably relate these spectrums to Venuti's foreignizing and domestication. Accordingly, macrostrategies have many different names given by different scholars. Some famous examples include:

Table 1. Translation macrostrategies

\begin{tabular}{lll}
\hline & Predominantly SL-Orientation & Predominantly TL-Orientation \\
\hline $\begin{array}{l}\text { Jean-Paul Vinay and Jean } \\
\text { Darbelnet }\end{array}$ & Direct translation & Oblique translation \\
Eugene Nida & Formal equivalence & \\
Peter Newmark & Semantic translation & Dynamic equivalence \\
Gideon Toury & Adequate translation & Communicative translation \\
Laurence Venuti & Foreignizing translation & Acceptable translation \\
Christiane Nord & Documentary translation & Domesticating translation \\
\hline
\end{tabular}

As mentioned above, macrostrategies are considered a choice that professional translators should take. According to Schjoldager et al. (cited in Jensen, 2009, p. 30), "Newmark, Venuti, Vinay, \& Darbelnet favour a source text or ST-oriented macrostrategy, whereas Nida prefers a target text or TT-oriented macrostrategy."

While microstrategies affect the larger unit, microstrategies work the other way around, in that, microstrategies affect a more specific level. Moreover, Chesterman (1991) (cited in Yang, 2010, p. 29) describes "local strategies at a specific level and the problem to be solved in translation is something like "how to translate this structure/this idea/this item"."

In this study, we use the microstrategies proposed by Schjoldager et al. (2008). Schjoldager et al.'s microstrategies are chosen because they are more specific and thorough. Schjoldager et al., proposed 12 microstrategies which, in this context, outnumber other strategies (Yang, 2010, p. 32). These microstrategies are: 


\begin{tabular}{ll}
\hline Direct transfer & Transfers something unchanged, e.g., paradox $\rightarrow$ paradox \\
\hline Calque & Transfers the structure or makes a very close translation, e.g., gag reflex $\rightarrow$ refleks gag \\
Direct translation & Translation in a word-for-word procedure, e.g., basic principle $\rightarrow$ dasar prinsip [sic]. The \\
& correct translation $\rightarrow$ prinsip dasar \\
Oblique translation & Translation in a sense-for-sense procedure, e.g., science $\rightarrow$ ilmu pengetahuan (knowledge) \\
Explicitation & Makes implicit information explicit, e.g., psychological studies $\rightarrow$ psikologi sosial (social \\
& psychology - one of the branches in psychology studies) \\
Paraphrase & Translates rather freely, e.g., effective $\rightarrow$ komprehensif (comprehensive) \\
Condensation & Translates in a shorter way, which may involve implication (making explicit information \\
& implicit), e.g. social psychology $\rightarrow$ psikologi (psychology) \\
Adaptation & Recreates the effect, entirely or partially, e.g., prison $\rightarrow$ lapas (it stands for Lembaga \\
& Pemasyarakatan (correctional center)) \\
Addition & Adds a unit of meaning, e.g., behaviorism $\rightarrow$ pendekatan behaviorisme (behaviorism approach) \\
Substitution & Changes the meaning, e.g., behaviorism $\rightarrow$ perilaku (behavior) \\
Deletion & Leaves out a unit of meaning \\
Permutation & Translates in a different place \\
\hline
\end{tabular}

According to Holst (2010, p. 8), these microstrategies outline two spheres of translation, namely translation with high degree of creativity and non-creative translation. The microstrategies that are included into high degree of creativity are substitution, permutation, adaptation, paraphrase, addition, deletion, condensation, and explicitation. On the other hand, non-creative translation microstrategies are oblique translation, direct translation, calque, and direct transfer. We contend that these microstrategies are used to build up the macrostrategies continuum of a text, i.e., creative and non-creative translation. This is in line with the theoretical thought of Holst (2010) who confirms that these macrostrategies are not seen from the perspective of SL and TL-orientation, but from the tendency to translate a text with more complex or in-depth text analysis.

The following classification clarifies the distinction between creative and non-creative translations:

\begin{tabular}{ll}
\hline High degree of creativity & Substitution \\
& Permutation \\
Adaptation & Paraphrase \\
& Addition \\
& Deletion \\
Condensation \\
Explicitation \\
\hline Non-creative & Oblique translation \\
& Direct translation \\
Calque \\
Direct transfer
\end{tabular}

In relation to the subjects' translation work, it is hoped that by clarifying these spheres, visually impaired translators can effectively use these microstrategies to tackle translation problems, because translation should not be taken for granted simply as changing a word for word, a phrase for phrase, a clause for clause.

\section{Method}

In order to collect the data, a translation task was assigned in this study. Two visually impaired translators were involved in the translation task. The first subject who is referred to as IH is a semi-professional translator. She lived in United States of America for two years, where she obtained her Master's degree in Social Studies. She has been working as a semi-professional translator for three years. Recently, she has also received translation trainings from one of the most reputable universities in Indonesia. The second subject who is referred to as SRT is also a semi-professional translator. Unlike $\mathrm{IH}$, he has never lived abroad or stayed in an English-speaking country. He has also been working as a semi-professional translator for three years. We noted that he never took any translation training.

In this study, the research subjects were asked to translate an English text into Indonesian. The text was taken from a book entitled "Psychology: The Science of Mind and Behavior" (Gross, 2008). We only took fifteen sentences from the second chapter of the book entitled "Theoretical Approaches to Psychology". 
The text itself is considered very difficult to read. The indicator was measured by using Flesch Reading Ease Readability Formula. The formula (Note 3) is as follows:

\begin{tabular}{lll}
\hline $\mathrm{RE}$ & $=$ & $206.835-(1.015 \mathrm{X}$ ASL)$-(84.6 \mathrm{X}$ ASW $)$ \\
\hline $\mathrm{RE}$ & $=$ & Readability Ease \\
$\mathrm{ASL}$ & $=$ & Average Sentence Length \\
$\mathrm{ASW}$ & $=$ & Average Number of Syllables per Word \\
\hline
\end{tabular}

Moreover, based on the formula, the text had 15 scales and was categorized as very difficult to read text with 355 words from 15 sentences and with an average of around 25 words per sentence as well as with an average of 3 syllables per word. Pertaining to the translation task, the translators were required to meet a one-hour translation deadline set through an agreement that came from both parties. During the translation process, they were able to use offline or online dictionaries and web search engine to help them translate the text. Moreover, although the term "translation strategies" was basically used to see the undergoing process of translation (Note 4), it was impossible to analyze the microstrategies used before receiving the final product of their work. Therefore, the need for a detailed analysis of the final translation accompanied by an investigation of the translators' translation process arose. After we received their translation, we analyzed the use of Schjoldager et al.'s microstrategies and reasons for the usage. We also included back translations into English to verify the accuracy of the translations and check for any inaccuracies of form and meaning produced by the translators.

\section{Findings and Discussion}

Based on the conducted translation task, the translators used only six microstrategies: direct transfer, direct translation, explicitation, paraphrase, addition, and deletion. As far as the diversity between translation microstrategies used by IH and SRT are concerned, we claim that SRT is a more creative translator than IH. This claim is supported by SRT's tendency to use more translation microstrategies with a high degree of creativity. In this case, he uses two non-creative microstrategies, namely direct transfer and direct translation, and four highly creative microstrategies, namely explicitation, paraphrase, addition, and deletion. Meanwhile, IH uses only two-non creative microstrategies, namely direct transfer and direct translation, and one creative microstrategy, namely explicitation. The findings can be elaborated in the following table.

Table 2. Frequency of translation macrostrategies

\begin{tabular}{lll}
\hline Microstrategy & N & \% \\
\hline IH & & \\
Direct transfer & 6 & $33 \%$ \\
Direct translation & 9 & $50 \%$ \\
Explicitation & 3 & $17 \%$ \\
TOTAL & 18 & $100 \%$ \\
\hline SRT & & \\
Direct transfer & 3 & $12 \%$ \\
Direct translation & 8 & $32 \%$ \\
Explicitation & 3 & $12 \%$ \\
Paraphrase & 3 & $12 \%$ \\
Addition & 4 & $16 \%$ \\
Deletion & 4 & $16 \%$ \\
TOTAL & 25 & $100 \%$ \\
\hline Visually Impaired Translators & \\
Direct transfer & 9 & $21 \%$ \\
Direct translation & 17 & $40 \%$ \\
Explicitation & 6 & $14 \%$ \\
Paraphrase & 3 & $7 \%$ \\
Addition & 4 & $9 \%$ \\
Deletion & 4 & $9 \%$ \\
TOTAL & 43 & $100 \%$ \\
\hline
\end{tabular}

From the findings shown in Table 2 above, it can be seen that the research subjects use direct translation as the dominant microstrategy (40\%). It implies that under deadline circumstances the translators have a tendency to 
apply direct translation as their default microstrategy. We observe that the tendency to use direct translation as their primary move comes from the fact that the translators use the screen reader that enacts word-for-word reading.

Visually impaired translators choreograph certain translation microstrategies pattern in their work, especially in generating non-creative translation microstrategies. In dealing with translation problems that require the absence of translation creativity, both research subjects always use direct transfer $(21 \%)$ and direct translation (40\%). There is a translation pattern that can be observed from the translation process, as shown in Table 3:

Table 3. Translation pattern

\begin{tabular}{ll}
\hline Microstrategy & Pattern \\
\hline Direct transfer & This microstrategy is used by both translators to translate jargons and terminologies related to \\
psychology studies. & IH frequently uses this microstrategy within the scope of simple sentence. \\
Direct translation & SRT commonly uses this microstrategy in two conditions: 1) within the scope of complex sentence \\
& and 2) in a sentence that has homonymic elements. \\
& This microstrategy is used by IH to translate a word or terminology that has the potential to create \\
Explicitation & confusion with its unclear reference. \\
& SRT uses this strategy to translate a word that is considered a general word to him. \\
Addition & The reaction of using this microstrategy is similar to that of Explicitation. It is used by IH to \\
& translate a word or terminology that has the potential to create confusion with its unclear reference. \\
& However, the result of the microstrategy does not significantly affect the quality of translation. The \\
& source language meaning shifts completely. On the contrary, SRT does not apply this microstrategy. \\
Paraphrase & SRT frequently uses this microstrategy within the scope of complex or compound complex \\
sentences. On the other hand, IH does not use this microstrategy. \\
SRT commonly uses this microstrategy in two conditions: 1) within the scope of complex or \\
Deletion & compound complex sentences and 2) in a sentence that contains a word considered unfamiliar \\
& tohim. In contrast, IH does not apply this microstrategy. \\
\hline
\end{tabular}

\section{Direct transfer}

Direct transfer means unchanging the form of SL. Accordingly, several theorists also use the term 'borrowing' to refer to this microstrategy. The analysis of this microstrategy can be seen in the excerpts below:

Excerpt 1

\begin{tabular}{lll}
\hline Source Language & Target Language & Back Translation \\
\hline By contrast, as Skinner (1987) & Sebaliknya, Skinner (1987) & By contrast, as Skinner (1987) asserts: \\
asserts: "Radical" behaviorists $\ldots .$. & menegaskan: "Radical" & "Radical" behaviorists ... recognise the \\
recognise the role of private events & $\begin{array}{l}\text { behaviorists ... mengenali peran } \\
\text { peristiwa pribadi }\end{array}$ & role of private events \\
\hline
\end{tabular}

Source: SRT's translation.

Excerpt 1 reveals that SRT uses direct transfer microstrategy to translate a psychological term "radical behaviorists". In respect to the theoretical standpoint above, we do not categorize direct transfer as pure or naturalized transfer; even some theorists correspond this microstrategy to the borrowing strategy that consists of pure and naturalized borrowings. Venuti (2000, p. 85) confirms that this microstrategy produces the simplest effort of all microstrategies.

We agree that translating well-established terminologies or jargons is tricky. Sometimes, it eases target readers, but, on the other hand, target readers are vulnerable to enter the pitfalls of faux amis when the juxtaposed terminologies or jargons incorporate different semantic fields. However, through the use of direct transfer strategy, the English and Indonesian texts correspond with each other.

\section{Direct translation}

Direct translation takes place as a word-for-word translation. The analysis of direct translation microstrategy is shown below: 
Excerpt 2

\begin{tabular}{lll}
\hline Source Language & Target Language & Back Translation \\
\hline Basic principles and assumptions & Prinsip-prinsip dasar dan asumsi & Principles basic and assumption \\
\hline
\end{tabular}

Excerpt 3

\begin{tabular}{|c|c|c|}
\hline Source Language & Target Language & Back Translation \\
\hline $\begin{array}{l}\text { In this sense, what was } \\
\text { revolutionary when Watson (1913) }\end{array}$ & $\begin{array}{l}\text { Dalam hal ini, apa yang dimaksud } \\
\text { dengan revolusioner ketika Watson }\end{array}$ & $\begin{array}{l}\text { In this case, what does revolutionary mean } \\
\text { when Watson (1913) first delivered his }\end{array}$ \\
\hline $\begin{array}{l}\text { first delivered his "behaviourist } \\
\text { manifesto"... }\end{array}$ & $\begin{array}{l}\text { (1913) pertama kali menyampaikan } \\
\text { pendekatan "manifesto behavioris"... }\end{array}$ & "behaviourist manifesto" approach(?)... \\
\hline
\end{tabular}

Source: IH's translation.

Płońska (2014, p. 70) claims that this microstrategy is "the default procedure used by a person translating a text". We suggest that this microstrategy becomes the dominant one because visually impaired translators apply word-centered reading through their screen readers. The use of direct translation results into a restriction of syntactic level, especially when translators deal with two languages having different syntactic patterns.

In excerpt 2, we notice that there is a syntactical shift in the translation of "basic principles and assumptions" into "prinsip-prinsip dasar dan asumsi". Here, "basic" serves as the premodifier for the head phrase "principles and assumptions". However, in the TL, the premodifier "basic" or "dasar" only modifies the head phrase "principles" or "prinsip-prinsip". The correct structure should be "prinsip dan asumsi dasar" ("basic principles and assumptions"). The same applies to the finding in Excerpt 3. SRT mistakenly conceives the word "what" in the affirmative clause "what was revolutionary" as an interrogative pronoun which turns the sentence into an interrogative clause.

The findings from both excerpts are similar. Visually impaired translators produce texts that contain syntactical errors, even when the target texts use the research subjects' native language. We come to a conclusion that JAWS screen reader contributes to this error, since its scope is limited only to word-for-word reading operation.

\section{Explicitation}

In this case, the translator tries to change an implicit expression or item in the SL into an explicit one in the TL by adding a thorough extension, as tabulated below.

Excerpt 4

\begin{tabular}{lll}
\hline Source Language & Target Language & Back Translation \\
\hline In this sense, what was & Dalam hal ini, apa yang dimaksud & In this case, what does revolutionary mean \\
revolutionary when Watson (1913) & dengan revolusioner ketika Watson & when Watson (1913) first delivered his \\
first delivered his "behaviorist & (1913) pertama kali menyampaikan & "behaviourist manifesto" approach(?)... \\
manifesto"... & pendekatan "manifesto behavioris"... & \\
\hline
\end{tabular}

Source: IH's translation.

Excerpt 5

\begin{tabular}{lll}
\hline Source Language & Target Language & Back Translation \\
\hline $\begin{array}{l}\text { It could be argued that all } \\
\text { psychologists are methodological } \\
\text { behaviorists... }\end{array}$ & $\begin{array}{l}\text { Dapat dinyatakan bahwa semua } \\
\text { psikolog adalah pendukung aliran } \\
\text { behaviorisme metodologis... }\end{array}$ & $\begin{array}{l}\text { It could be argued that all psychologists are } \\
\text { the supporters of methodological } \\
\text { behaviorism theory... }\end{array}$ \\
\hline
\end{tabular}

Source: SRT's translation.

The explicitations evidenced in Excerpt 4 and 5 show that the subjects try to make the terminologies or jargons in the text as informative as possible. Consequently, the translators realize that specific terminologies or jargons are likely to be associated with specific encyclopedic knowledge a reader has. However, to assist readers who have lack of specific encyclopedic knowledge, explicitation on certain specific terminologies or jargons is barely needed.

This proves that the research subjects are aware that communicative conventions which link the text and readers' 
schema offer clearer understanding of the message of the author. Both translators argue that in Indonesian psychological discourse, the use of "behaviorist manifesto" and "methodological behaviorists" are commonly accompanied by "approach" and "the person who supports (methodological behaviorism) theory", respectively.

\section{Paraphrase}

This is used when SL items and their meanings are transferred into the TL, but they are changed pretty freely and it is sometimes difficult to predict the real message of the SL when the technique is applied. The analysis of this microstrategy can be seen below:

\section{Excerpt 6}

\begin{tabular}{|c|c|c|}
\hline Source Language & Target Language & Back Translation \\
\hline $\begin{array}{l}\text { For Skinner, these more effective } \\
\text { explanations of behavior come in } \\
\text { the form of the principles of } \\
\text { reinforcement derived from his } \\
\text { experimental work with rats and } \\
\text { pigeons }\end{array}$ & $\begin{array}{l}\text { Bagi Skinner, penjelasan tentang } \\
\text { perilaku yang lebih komprehensif } \\
\text { diwujudkan dalam bentuk dasar-dasar } \\
\text { penguatan (principle of reinforcement) } \\
\text { yang berasal_dari penelitiannya dengan } \\
\text { tikus dan burung merpati }\end{array}$ & $\begin{array}{l}\text { For Skinner, these more comprehensive } \\
\text { explanations of behavior are realized into } \\
\text { the form of the principles of reinforcement } \\
\text { coming from his experiment with rats and } \\
\text { pigeons }\end{array}$ \\
\hline
\end{tabular}

Source: SRT's translation

Callison-Burch (2007, p. 11) suggests that "paraphrases are alternative ways of expressing the same content". We argue that this microstrategy is the core of creativity in translation. The stance is in consonance with the finding shown in Excerpt 6. We discover that SRT, as the sole translator who applies this microstrategy, appropriately expresses some linguistic items in the SL in different forms.

We can see that each of the translation evidence above is aligned with its English counterpart, or in other words, the translator allows himself to translate any linguistic unit to which they can apply a suitable translation without the urgency to preserve SL surface level. In this case, we notice that the translator breaks the habit of word-for-word operation by making a fluid interpretation of the text. Thus, synonymous words, reinterpretation of idiomatic expressions, and linguistic simplification (Note 5) have been used to express the idea in different forms of words.

\section{Addition}

As the name suggests, "addition" is used to classify translations that include another unit of meaning which is not inherent in the SL. In this microstrategy, the added unit of meaning cannot be deduced from the original SL. The analysis of addition can be seen below:

\section{Excerpt 7}

\begin{tabular}{lll}
\hline Source Language & Target Language & Back Translation \\
\hline The behaviorist approach & Pendekatan metoda perilaku & The behavior approach method \\
\hline
\end{tabular}

Source: SRT's translation

As Nida (1964) suggests, the use of addition microstrategy aims to clarify specific terms or cultural references that have the potential to mislead readers' perceptions. In addition, this microstrategy prepares a different group of target readers who are not equipped with the same background schemata. However, from excerpt 7 above, we can identify that SRT alters the meaning of SL by adding the word "metoda" or "method" in his translation. The translator argues that he needs to clarify the term "behaviorist" into "behavior" + "method".

We agree that, in this case, his point of view is misleading and this addition must have not been used in the translation. We affirm that the use of this microstrategy is mainly triggered by the translator's interpretation. In fact, the addition of the word "metoda" is not necessary, because it creates redundancy in the TL.

\section{Deletion}

As its name tells, this microstrategy leaves out some SL elements in the TL. The analysis of the microstrategy of deletion can be seen below: 
Excerpt 8

\begin{tabular}{|c|c|c|}
\hline Source Language & Target Language & Back Translation \\
\hline $\begin{array}{l}\text { Belief in the importance of } \\
\text { empirical methods, especially the } \\
\text { experiment, as a way of collecting } \\
\text { data about humans (and } \\
\text { non-humans), which can be } \\
\text { quantified and statistically } \\
\text { analysed, is a major feature of } \\
\text { mainstream psychology }\end{array}$ & $\begin{array}{l}\text { Meyakini pentingnya metode empiris, } \\
\text { khususnya penelitian tentang } \\
\text { pengumpulan data manusia (dan bukan } \\
\text { manusia) yang dapat diukur, penting } \\
\text { bagi psikologi mainstream }\end{array}$ & $\begin{array}{l}\text { Believing in the importance of empirical } \\
\text { method, especially the experiment of } \\
\text { collecting data about humans (and } \\
\text { non-humans), which can be quantified, is } \\
\text { major for mainstream psychology }\end{array}$ \\
\hline
\end{tabular}

Source: SRT's translation.

In contrast to addition, this microstrategy omits some SL linguistic items or information in the translation. Deletion is usually used to conform to medium restriction, as in subtitling. Baker (1992, p. 40) states that "this strategy may sound rather drastic, but, in fact, it does not cause any harm to avoid translating a word or expression in some context". Excerpt 8 shows that SRT deletes linguistic items ranging from word to phrase.

We claim that deletion does not bring any serious implication towards text informativity. We observe that the deletion micostrategy applied by SRT does not have the tendency to omit elements at clause or sentence level. This implies that the translator is fully aware that clauses and sentences provide crucial information for readers, thus deleting a clause or sentence is seen as a formidable move by SRT.

\section{Conclusion}

Of the six microstrategies applied by the subjects of the present research, three indicate high degree of creativity and these microstrategies are used by a visually impaired translator who has poorer English proficiency and less translation training. In contrast, the nature of translation microstrategies which are meant to give maximum result turns out to give an opposite effect.

Furthermore, microstrategies of translation can also hazard the translation if they are not properly used. The research subjects also perform direct translation as their prevalent choice $(40 \%)$ when translating a text. However, the tendency is due to the fact that the translators rely excessively on the screen reader that performs word-for-word operations. Consequently, this outcome does not lead to translation flexibility that allows changes at the surface level.

\section{References}

Archer, J. (2002). Internationalisation, Technology and Translation. Perspectives Studies in Translatology, 10, 87-117. http://dx.doi.org/10.1080/0907676X.2002.9961437

Asensio, R. M. (2007). Specialised Translation: A Concept in Need of Revision. Babel, 53(1), 48-55. http://dx.doi.org/10.1075/babel.53.1.05may

Baker, M. (1992). In Other Words. London: Routledge. http://dx.doi.org/10.4324/9780203327579

Callison-Burch, C. (2007). Paraphrasing and Translation (thesis). University of Edinburgh. Retrieved from https://www.cs.jhu.edu/ ccb/publications/callison-burch-thesis.pdf

Cronin, M. (2003). Translation and Globalization. London and New York: Routledge.

Gross, R. (2010). Psychology: The Science of Mind and Behaviour (6th ed.). London: Hodder Education.

Hernández-Bartolomé, A. I., \& Mendiluce-Cabrera, G. (2004). Audesc: Translating Images into Words for Spanish Visually Impaired People. Meta, 49(2), 264-277. http://dx.doi.org/10.7202/009350ar

Holst, J. L. F. (2010). Creativity in Translation-A Study of Various Source and Target Texts. Institut for Sprog og Erhvervskommunikation: Aarhus School of Business. Retrieved from http://pure.au.dk/portal-asb-student/files/11416/Creativity_in_Translation.pdf

Jensen, M. N. (2009). Professional Translators' Establishment of Skopos-A “Brief” Study. Institut for Sprog og Erhvervskommunikation: Aarhus School of Business. Taken from http://pure.au.dk/portal-asb-student/files/7795/Professional_Translators_Establishment_of_Skopos.pdf

Königs, F. G., \& Kaufmann, R. (1996). Processus Mentaux Étudiés Chez des Sujets Apprenant Le Français Lorsqu'ils Sont en Train de Traduire. Meta, 41(1), 7-25. http://dx.doi.org/10.7202/003341ar 
Lörscher, W. (2002). Translation Process Analysis within a Framework of Systemic Linguistics. In C. Todenhagen (Ed.), Text-Text Structure—Text Type. Festschrift for Wolfgang Thiele (pp. 117-127). Tübingen: Stauffenburg Verlag.

Margetic, E. (2011). The Making of a Professional Translator. Multilingual, April-May, 38-39.

Mcgonigle, F. (2007). The Audio Description of Children's Films (Unpublished thesis). University of Surrey.

Molina, L., \& Albir, A. H. (2002). Translation Technique Revisited: A Dynamic and Funcsionalist Approach. Meta, 47(4), 498-512. http://dx.doi.org/10.7202/008033ar

Newmark, P. (1988). A Textbook of Translation. London: Prentice-Hall International.

Nida, E. (1964). Toward a Science of Translating. Leiden: E.J. Brill.

Owji, Z. (2013). Translation Strategies: A Review and Comparison of Theories. Retrieved from http://translationjournal.net/journal/63theory.htm

Płońska, D. (2014). Strategies of Translation. Psychology of Language and Communication, 18(1), 67-74. http://dx.doi.org/10.2478/plc-2014-0005

Pym, A. (1998). Method in Translation History. Manchester: St. Jerome Publishing.

Romero-Fresco, P. (2011). Subtitling through Speech Recognition: Respeaking. Manchester: St. Jerome Publishing.

Schjoldager, A., Gottlieb, H., \& Klitgård, I. (2008). Understanding Translation. Aarhus: Academica.

Suryandaru. (2011). Strategies in Translating Articles of News on the Websites: A Case Study of a Blind Translator Translating Articles of News on Dompet Duafa Website (Unpublished thesis). Dian Nuswantoro University.

Theologitis, D. (1998). The Impact of New Technology on the Translator. Terminologie et Traduction, 1, 342-351.

Tirkkonen-Condit, S. (2005). The Monitor Model Revisited: Evidence from Process Research. Meta, 50(2), 405-414. http://dx.doi.org/10.7202/010990ar

Venuti, L. (2000). The Translation Studies Reader. London and New York: Routledge. http://dx.doi.org/10.4324/9780203446621

Yang, Y. (2010). Syntactic Translation Strategies in Finnish-Chinese Translation: A Case Study on the Great Fairy Tales of the Finissh People into Chinese (thesis). University of Tampere. Retrieved from https://tampub.uta.fi/bitstream/handle/10024/81696/gradu04389.pdf? sequence=1

\section{Notes}

Note 1. In fact, Ott (in Margetic, 2011, p. 38) states that "translation is not for people who love the outdoors". This statement refers to those translators who sit in front of computers for hours in the translation process.

Note 2. Specialized Translation is divided into two different axes: horizontal (extensive) and vertical (intensive). The former studies the subject matter of a text, while the latter explores the grade of specialization of a text. The study of translation and disabled people lies on the vertical (intensive) axis (Asensio, 2007).

Note 3. http://www.readabilityformulas.com/flesch-reading-ease-readability-formula.php

Note 4. See Molina \& Albir (2002) for a distinction between translation strategies and techniques.

Note 5. In respect to the theoretical framework above, it is categorized as condensation.

\section{Copyrights}

Copyright for this article is retained by the author(s), with first publication rights granted to the journal.

This is an open-access article distributed under the terms and conditions of the Creative Commons Attribution license (http://creativecommons.org/licenses/by/4.0/). 